\title{
AZ ALFÖLD INFRASTRUKTÚRÁJÁNAK JELLEMZŐI ÉS FŐBB FEJLESZTÉSI FELADATAI
}

\author{
(Peculiarities of the Infrastructure in the Great Hungarian Plain)
}

\section{ERDŐSI FERENC}

\section{Problémafelvetés}

Korunkban a gazdasági struktúraváltás egyik elmaradhatatlan jellemzổe, hogy a termelési szférával szemben növekszik a tágabb értelemben vett szolgáltatások súlya mind az értéktermelésben, még gyorsabban a foglalkoztatásban. E folyamat nem hagyja érintetlenül a társadalmat sem. Bizonyos embrionális jelei már nálunk is vannak az, ,ipar utáni" (posztindusztriális, információs) társadalom felé fejlôdésnek.

Nemcsak a termelổi, de a lakossági szolgáltatások tárgyi-intézményi alapját, hálózatát is az infrastruktúra képezi. E szféra ágazati és térségi vonatkozásban egyaránt elôtérbe kerül, mindinkább a település- és területtervezés kardinális tényezôjének rangját viseli. Anélkül, hogy kitérnénk az infrastruktúra fogalommal kapcsolatos értelmezési problémákra, sietünk leszögezni, hogy bár kívánatos lenne a legkorszerúbb (a bankrendszert, a tũz-, víz, honvédelmi, közbiztonsági intézményeket stb. magába foglaló) infrastruktúra fogalommal dolgozni, azonban vizsgálatainkat kénytelenek vagyunk a statisztikai adatszolgáltatás meglehetôsen hagyományos rendszeréhez igazodva végezni.

A tényfeltárás során arra a kérdésre igyekeztünk választ adni, hogy a különféle infrastruktúrák fejlettségében milyen az Alföld pozíciója az országos átlaghoz, a többi országrészhez viszonyítva, továbbá az Alföldön belül milyen regionális (megyék közötti), települési (főként városok közötti) differenciák tapasztalhatók, milyen a fejlôdés dinamikája (növekszik-e a szakadék az országrészek között, az Alföldön belüli területek között, vagy felzárkózási folyamatok érvennyesülnek). Igyekeztünk feltárni a fejlôdés, illetve a differenciálódási folyamat okait, mozgatórugóit, az Alföld általános természeti, gazdasági-társadalmi viszonyainak, geopolitikai helyzetének az infrastruktúrára gyakorolt hatását.

Az elemzés tanulságainak, az általános társadalmi-gazdasági átalakulás fổbb elemeinek, jellemzőinek figyelembevételével vázoltuk fel az Alföld infrastruktúra-fejlesztésének stratégiáját és fổbb feladatait, rámutatva az infrastruktúra (korlátokat sem nélkülözô) lehetốségeire a területfejlesztésben, valamint az infrastruktúra-fejlesztés lehetséges szervezeti és pénzügyi eszközrendszerére. Az olvasó feltehetôen hiányolja, hogy nem fogalmaztuk meg konkrétan, milyen infrastruktúrára, illetve fejlesztésekre van szükség az Alföldön. 
Ez semmiképpen nem történhet (népességre, területegységre vetített fajlagos) ,,normák” alapján, hanem csakis az egyes kisrégiók, települések funkcióit, konkrét igényeit és lehetôségeit számba vevổ területi tervezés keretében. A tervezés viszont már mások feladata.

\section{Tényfeltárás}

\section{A lakossági infrastruktúra ágazati jellemzói}

\section{a) Lakásviszonyok - közmüvesitettség}

A lakossági infrastruktúra terén az Alföld elmaradottságának mértéke az utóbbi fél évszázad alatt csökkent. Különösen a lakásellátottságban (a laksũrüségben, kiváltképpen pedig a lakásnagyságban) jelentôs a közelítés az országos átlaghoz, sốt némely mutatóban felzárkózás ment végbe. A lakásépítés dinamikája az 1970-1980-as években az átlagosnảl gyorsabb volt, ennek következtében a lakásállomány ma viszonylag ,fiatalos", egészségesnek mondható. A lakásellátottság mértéke, az újszerũ lakások aránya sok esetben a jövedelmektôl függetlenül, sốt azokkal ellentétesen alakul. Szabolcs-Szatmár-Bereg megye kiemelkedôen kedvezô helyzetét például részben az önzsigerlõ életmódnak, részben vis maiornak köszönheti (árvíz utáni, jórészt országos forrásokból végrehajtott újjáépítésnek).

$A$ közmüves ellátottság terén viszont az igen alacsony szintrốl induló látványos fejlôdés ellenére még mindig nagyon erốs az elmaradottság. Különösen a vízellátás és a csatornázottság terén sok még a teendô. Az alföldi lakásoknak ugyanis bõ háromnegyedébốl a szennyvíz csövön távozik, de ezeknek csupán egyharmada van bekötve szennyvíztelephez csatlakozó közcsatorna-hálózatba.

Környezetvédelmi szempontból különös fontosságú a közmüolló nyitottságának mértéke. A legnagyobb arányban a megyeszékhelyeken zárkózott fel a csatornázottság a vízellátáshoz (csak 1,25-1,69-szeres különbséggel), míg a többi város közül Záhonyban 1,1, Baján és Mátészalkán (1,8-1,8), Martfün, Vásárosnaményben 1,9-szeres e különbség. ${ }^{1}$

A szénmedencék távolsága miatt csak a legnagyobb, illetve legurbanizáltabb városokban mũködött gázgyár, így az Alföld gázellátása csupán töredékét tette ki az országosnak. A földgáz elổtérbe kerülésével az Alföld (saját lelôhelyei és az import jóvoltából) a többi országrészhez képest kedvezőbb helyzetbe került.

Az Alföld rendkívüli elmaradottságát a lakások komfortszintje, vízöblítéses WC-vel, fürdôszobával való ellátottsága tekintetében erôsen ledolgozta, de még ma sem jelentéktelen a hátránya a többi országrészhez képest.

A lakásállomány falazatának és padozatának anyaga tekintetében viszont az Alföld még ma is meglehetốsen hagyományos karakterú. Nem biztos, hogy a vályog és döngölt föld 
falanyagként történt szélesebb körũ alkalmazása elmaradottságot is jelent. Kiváló hổszigetelổ tulajdonságai miatt a fejlett országokban reneszánszát éli ez a természetes építổanyag, sốt betonvázzal kombinálva többemeletes házak is épülnek a vályogból.

A tágabb értelemben vett lakásviszonyok (lakásellátottság, -felszereltség, közmũvekkel való ellátottság) valamennyi elemét figyelembe véve az alföldi megyék közül Csongrád megye helyzete a legjobb, Pest megye a második, Bács-Kiskun a harmadik. A további sorrend: negyedik Hajdú-Bihar, ötödik és hatodik holtversenyben Békés és SzabolcsSzatmár-Bereg, az utolsó, hetedik helyen pedig Jász-Nagykun-Szolnok megye áll. Meg kell jegyeznünk, hogy az ellátottság megyei mennyiségi értékei között csekély a különbség, azaz a szóródás. A fél évszázaddal korábbi helyzethez képest közeledtek egymáshoz a megyék jellemzôi.

Az alföldi városok közül a megyeszékhelyek közepes mértékủ és egymáshoz meglehetôsen közelálló értékú laksưrüségűek, a nagy lakások gyakorisága is csak gyenge-közepes vagy közepes mértékũ. A lakások komfortszintje, közmũvesítettsége viszont igen magas. Mindez a - fốként paneles - tömeges lakótelep-építés eredménye. Hat részjellemzổbôl komplex lakásellátottsági-komfortszint-közmũvesitettségi mutatót képezve (Pest megye igazgatási székhelyétôl, Budapesttől eltekintve) Szeged vezet, Szolnok a második, Debrecen a harmadik, Békéscsaba a negyedik, Nyíregyháza az ötödik és Kecskemét a legutolsó helyen áll. A többi város lakásállományát az átlagosnál valamivel nagyobb és erósen szóródó laksưrüség, valamint az ugyancsak erốsen különbözó lakásnagyság jellemzi.

Feltũnõen magas a nagy lakások aránya a Duna-Tisza közi (hagyományos intenzív mezógazdasági kultúrákból nagy jövedelmet kitermelô) kisvárosokban, valamint egyes szatmári kisvárosokban, legalacsonyabb a nagykunsági, hajdúsági, bihari, jászsági és szabolcsi kisvárosokban, továbbá a nagyrészt lakótelepi karakterũ ipari településen, Martfûn. Komfortszint, közmũvesítettség tekintetében a hagyományos, erôsebben urbanizált speciális (kereskedelmi, ipari, egyházigazgatási, vasúti csomópont) funkciójú települések, valamint a szatmári kisvárosok járnak elöl (elérve a megyeszékhelyek átlagát), míg a legalacsonyabb komfortszintũek a szélsôségesen agrárfunkciójú, részben periférikus fekvésũ, városi ranghoz csak az utóbbi évtizedekben jutó kisvárosok. A sokszoros különbség a nem megyeszékhely városok közmûvesítettségében elsôsorban nem a jövedelmi differenciák mentén alakult ki. E diszkrepanciák létrejöttében még csak nem is annyira más objektív, mint inkább szubjektív tényezổk játszottak közre.

b) Kommunális (közösségi) intézményi infrastruktúra

Az oktatási-mưvelôdési infrastruktúrán belül az óvodai ellátás (a zsúfoltság mértéke alapján) alig valamivel gyengébb az országos átlagnál, ugyanez a helyzet az általános, sốt a középiskolák vonalán is. (A középiskolák egy osztálytermére jutó tanulók száma tekintetében pedig jobb helyzetnek örvend az Alföld.) Legrosszabb a helyzet a szakmunkásképzésben, ahol legnagyobb probléma a szakoktatóhiány. A felsốoktatás mennyiségi mutatói tekintetében is hátrányos az Alföld helyzete, és különösen kifogásolhatók a szak- 
irányultság szerinti aránytalanságok; a képzés szakmai szerkezete nem felel meg a nagyrégió belsô szükségleteinek. Különösen hiányzik, illetve igen kis kapacitású a múszaki, közgazdasági felsõoktatás, miközben agrárszakemberekbõl és pedagógusokból viszonylagos túlképzés történik. Az újsütetũ fổiskolák jellemzổje, hogy nagy részük nem önálló, hanem túlnyomóan fổvárosi egyetemek és fổiskolák, kisebb részben alföldi egyetemek és dunántúli fổiskolák tagozata. A mũvelôdési intézmény ellátottság terén - ha térségileg koncentrált formában is - sikerült megközelíteni az országos átlagot, viszont a kutatófejlesztô tevékenységben nagy az elmaradás, nem annyira a többi országrészhez képest, mint a fôváros által nyomasztóan súlyozott országos átlaghoz viszonyítva.

Az Alföldön belül az egyes megyék közötti sorrend eltérôen alakul a különféle oktatási szintek tekintetében.

$\mathrm{Az}$ óvodai ellátásban a legjobb helyzetet Szabolcs-Szatmár-Bereg és Bács-Kiskun megye élvezi, legrosszabb a helyzet Hajdú-Bihar és Pest megyében. Az általános iskolai ellátottságban Csongrád és Békés megye vezet, Bács-Kiskun és Pest a sereghajtók. A középiskolai ellátás terén pedig Pest és Békés van a legjobb, Szabolcs-Szatmár-Bereg és Bács-Kiskun megye pedig a legrosszabb helyzetben. Mind a három oktatási szintet együtt nézve, Csongrád és Békés osztozkodik holtversenyben az elsõ két helyen, majd SzabolcsSzatmár-Bereg és Jász-Nagykun-Szolnok következik, míg azonos osztályzat értékkel a legrosszabb helyzetửnek Bács-Kiskun, Hajdú-Bihar és Pest megye ítélhetô. A kutató-fejlesztố helyek terén - a létszám alapján - azok a megyék vezetnek, amelyeknek egyetemeik vannak: Pest, Csongrád, Hajdú-Bihar; a negyedik és ötödik helyen Békés és Szabolcs-Szatmár-Bereg megye következik, az utolsó két helyen pedig Jász-NagykunSzolnok és Bács-Kiskun megye áll.

A tanulók száma, részesedési aránya a népességbốl a városonként nagyon differenciáltan alakuló demográfiai viszonyok függvénye. Idôközbeni igényváltozáshoz az iskolák kapacitása nagyon nehezen tud alkalmazkodni. Átmenetinek ígérkezô, de még tartósnak mutatkozó létszámnövekedés esetén is csak kevés helyen képesek a problémát építkezéssel járó bõvitésekkel megoldani. Már az is nagy eredmény, ha bérlettel növelik a befogadóképességet. (Amennyiben egyáltalán található az adott városban közegészségügyi szempontból is magas követelményeknek megfelelô épület, termekkel.) Pedagógusok felvétele viszont csupán pénz kérdése a városokban, általában e szakma munkaerôpiacán a kínálat mind több helyen felülmúlja a keresletet. ${ }^{2}$

Az Alföld elsõ számú felsôoktatási (egyetemi) központja Szeged (amely mindjárt a fôváros után következik az országos hierarchiában), a második Debrecen. Csupán fổiskola müködik Nyíregyházán, Kecskeméten, Szolnokon, Baján, Szarvason, Jászberényben, Hajdúböszörményben, Békéscsabán, Hódmezôvásárhelyen és Mezốtúron.

Az egészségügyi ellátás terén is észrevehetōen csökkent az Alföld elmaradottsága. Sốt, a körzeti orvosi és gyermekorvosi ellátottságban már országos átlag körüli állapot jellemzõ az Alföldre. A kórházi kapacitásban ugyan jelentôs lemaradás mutatkozik az orsz- 
ágos átlaghoz képest, de - az ország kórházi ágyainak közel egyharmadát magáénak tudó fôváros nélküli - a vidéki átlaghoz mérve, már alig van különbség. A bölcsôdei és szociális otthoni (férōhely) ellátottságban az Alföld már nagyjából elérte, illetve megközelítette az országos szintet, de így is nagy a zsúfoltság.

Az Alföldön belül az orvosellátottság mértékére rányomja bélyegét az orvostudományi egyetemek elhelyezkedése. (Csongrád és Hajdú-Bihar megye áll az élen, Pest megye az utolsó, erổsen leszakadva az elôtte levôktổ.) Valamelyest másként alakul a kórházi ellátottság területi képe, Hajdú-Bihar megye - nagy kapacitású klinikái ellenére - például Jász-Nagykun-Szolnok megye mögé szorul. A szociális otthoni ellátottság a legsiralmasabb Pest és Szabolcs-Szatmár-Bereg megyében (országos viszonylatban is a legrosszabb), az országos átlagot Csongrád és Hajdú-Bihar éri el, illetve haladja meg e téren.

A lakosság egészségi állapotában, korösszetételében nincsenek olyan jelentôs különbségek sem a megyeszékhelyek, sem a többi város között, hogy indokolt lenne az orvosi ellátottság tekintetében a megyeszékhelyek kategóriáján belül észlelt több mint kétszeres, a többi város között pedig éppenséggel tizenkétszeres különbség, ezért itt a valós lakossági ellátási igényektôl függetlenítôdött, számos szubjektív tényezô által alakított torz állapottal állunk szemben. Hiszen ha valamiben, úgy éppen ebben az infrastruktúrában kellene a lehetô legnagyobb egyenletességet biztosítani, ugyanis ezt diktálja az ember szociális igazságérzete.

Kórház müködik minden megyeszékhelyen, viszont a többi városnak csupán a felében. Ebbốl következôen jó néhány városnak nemcsak a saját körzetét, hanem a szomszédos általános vonzáskörzetet, vagy annak egy részét is el kell látnia kórházi egészségủgyi szolgáltatással. A saját népességszámukhoz képest sok ággyal rendelkezó kórházak mintegy „,kórházvárossá” vagy ,,gyógyító centrummá” avatnak olyan kisvárosokat is, mint Kisvárda, Mátészalka, Vásárosnamény, Fehérgyarmat, Baja, Berettyóújfalu, Gyula, Kalocsa, Kiskunhalas stb. Ezeknek a városoknak a kórházai több általános (pl. belgyógyászati, sebészeti, szülészeti-nôgyógyászati) és néhány speciális (pl. onkológiai, urológiai, ideggyógyászati, orr-fül-gége) osztállyal is rendelkeznek.

c) Kiskereskedelmi-idegenforgalmi infrastruktúra

A kiskereskedelmi infrastruktúra, a bolthálózat jellemzõje, hogy mennyiségi téren, a bolti alapterület fajlagos adatai tekintetében az Alföld megközelítette az országos átlagot, de ez a fejlớdés az átlagosnál erôsebb koncentrációval ment végbe. Nevezetesen, a nagyvonalú áruházépítési program eredményeként erốsebben csökkent a boltok száma, mégpedig szakjelleg szerint is differenciáltan, különösen a kis falusi boltok sokaságának megszünésével. Kedvezốtlenebbé vált tehát az áruterítés a tanyasi-falusi lakosság körében. E helyzeten az utóbbi idôszakban felgyorsult privatizáció sem segített igazán, mivel az új ,,maszek” kisboltok, butikok túlnyomó része is a nagyobb településeken, városokban jött létre. Az utóbbi években megcsappant , vásárlási kedv” alapján általában 
elegendỗnek látszik a szakbolti kapacitás egésze, inkább a szakstruktúra terén mutatkozik igény a változtatásra. A valós keresletszerkezet azonban a kiskereskedelmi piaci viszonyok között is csak lassan alakul ki, mert a kereskedô az elérhetố nyereséghányad alapján dönt a bolt profiljáról. A kiegyenlítô tendencia ellenére a fajlagos kiskereskedelmi forgalom tekintetében is elmarad az Alföld az országos átlagtól. ${ }^{3}$

Négy kiskereskedelmi és idegenforgalmi részmutatóból képzett komplex mutató szerint a megyeszékhelyek közül összességében a legjobb helyzetben Szeged van Szolnokkal együtt, majd a harmadik és negyedik helyen holtversenyben Békéscsaba és Kecskemét adja a középmezổnyt, a legkedvezôtlenebb helyzet pedig Debrecenre és Nyíregyházára jellemzõ.

Ezen belül a kiskereskedelmi infrastruktúra terén Békéscsaba és Szolnok vezet, Szeged és Debrecen helyzete a legrosszabb. Hangsúlyoznunk kell azonban, hogy a megyeszékhelyek szũk csoportján belül jelentéktelenek a tényleges különbségek (a szélsô értékek kb. 15\%-kal különböznek), viszont a többi város állományán belül a szélsô értékek 8,5-szeresen térnek el egymástól. Olyannyira, hogy vannak olyan kisvárosok, amelyek bolthálózata - lakosságukhoz mérten - még a megyeszékhelyekhez képest is fejlettebb (Bácsalmás, Fehérgyarmat, Berettyóújfalu, Baja, Kalocsa, Mátészalka, Kisvárda, Vásárosnamény stb.). Feltũnõen sok közöttük a szatmári, ahol már nem tud érvényesülni Nyíregyháza igen erôs kereskedelmi vonzása.

Az idegenforgalmi infrastruktúra alapját képezõ ,,kereskedelmi szálláshelyekbốl" az Alföld mind területéhez, mind népességszámához, de még adottságaihoz képest is aránytalanul csekély mértékben (egyötöd arányban) részesedik.

Az Alföldön belül, az egyes megyék között a szállodai férôhelyek és a fizetôvendégszobák számában sokkal kisebb a szóródás, mint a kempingeknél. A hosszabb tartózkodásra alkalmas szálláshelyek erôsen a gyógyvizekhez kötôdnek, amit Hajdú-Bihar megye fölénye is igazol, míg a kempingek a nyári idényben hathatósan besegítenek a gyógyidegenforgalomba, a vízparti üdülésbe, emellett egész évben a tranzitforgalmat is szolgálják. Amennyire képes volt a minimális befektetést igénylô fizetôvendéglátás a legrugalmasabban igazodni az adott térség keresletéhez, a jóval tốkeigényesebb kempingekkel való ellátásban igen nagy és az idegenforgalmi potenciállal összefüggésbe nem hozható különbségek léteznek. (Jellemzô, hogy Hajdú-Bihar kempingjei tizenötször annyi vendég befogadására alkalmasak, mint a gyógyfürdôkkel, vízparti üdülökkel ugyancsak rendelkezô Békés megyeiek.)

Városi viszonylatban a szálláshely-kapacitás a legnagyobb mértékben az országos hírũ fürdöhelyen, Hajdúszoboszlón összpontosul; második Debrecen, harmadik Szeged. Ezután néhány népes megyeszékhely következik (Szolnok, Kecskemét, Nyíregyháza), majd nem a népességszám alapján, hanem az idegenforgalmi adottságok mértéke szerint alakul a további sorrend. Tehát Szoboszlót leszámítva a megyeszékhelyek idegenforgalmi szálláshely-kapacitása a legnagyobb, Békéscsaba kivételével, amely (424 fốs értékével) 
még az elsô 15 közé sem kerül be. A megyeszékhelyek kapacitása csak részben tükrözi az általános (ügyintézéssel kapcsolatos) forgalom méretét, a legtöbb esetben azt valamilyen üdülési-idegenforgalmi szerepkör ellátása is indokolja.

A többi város közül a kapacitás viszonylagos nagyságával a melegvizes gyógyfürdốhelyek, valamint a Tisza- és a Duna-parti idényjellegü természetes fürdôhelyek tủnnek ki. Esetenként a nemzetközi tranzifforgalom is elôsegíti az idegenforgalmi infrastruktúra erôsödését, noha 11 alföldi városban semmiféle idegeneknek kiadható szállás nincs.

\section{A lakossági infrastruktúra fejlettségének települési kategóriák szerinti jellemzối}

Az Alföld mai infrastrukturális állapotát részben az egész országra jellemzó folyamatok, ,,tervgazdasági" intézkedések, normák, részben különleges adottságai (a nagyfalvas-tanyás településszerkezet, a mezôgazdaság, és az agrárnépesség nagyobb aránya, a paraszttársadalmi múlt, továbbá, hogy a keleti energiaimport fogadóterülete, hogy a nemzetközi tranzitközlekedés fontos szereplōje, hogy iparositása más országrészekhez képest jóval visszafogottabb volt, $s$ területén alig épültek nagy infrastruktúra vonzatú iparvárosok, végül az alacsonyabb szintú idegenforgalmi igények) eredményezték. Az uralkodó terület- és településpolitikai magatartásnak megfelelôen a lakossági infrastruktúra-fejlesztés elsôsorban a megyeszékhelyeken összpontosuló tömeges lakásépítéshez kötôdött.

a) A városok infrastrukturális viszonyai

Az Alföld városállományának infrastrukturális fejlesztése meglehetốsen differenciáltan történt, és a sajátos infrastrukturális problémák nagyságrend és funkció szerinti kategóriánként eltérố módon jelentkeztek az egyes városokban. Legelhanyagoltabbak az agrárstruktúrájú kisvárosok (különösen a nagykunsági és hajdúvárosok) és egy ideig a határközeli városok (az 1950-es években Szeged, Baja stb.) voltak. Városkategóriánként ma is különböznek az infrastruktúra feszültségforrásai (pl. a lakáshelyzet rosszabb a nagyvárosokban, mint a közép- és kisvárosokban, a közmüvesítettség, a hírközlés pedig fordított képet mutat). ${ }^{4}$

Az elmúlt évtizedben a várossá nyilvánítás az Alföldön is meglehetổsen megalapozatlanul tơrtént. Az új kisvárosok kommunális infrastruktúrájának színvonala messze nem kielégítő. Jó néhányuknak nincs középiskolája, kórháza. Így ahelyett, hogy környékük vonzásközpontjai lennének, lakosaik a legalapvetôbb középfokú szolgáltatások igénybevételéhez kénytelenek máshová ingázni, azaz maguk is a ,,vonzott település" szituációját kénytelenek megélni.

Az Alföldön is kialakultak többé-kevésbé kompakt, az egymáshoz közeli fekvés elônyeit élvezố településegyüttesek. Nagyon sajnálatos, hogy az együttmũködési lehetôségek kínálta elỡnyöket (elsősorban területkutatók részérôl történt kezdeményezések ellenére) nem sikerült hasznosítani az infrastruktúra-fejlesztések során (pl. a közép-békési városré- 
gióban, a szolnoki agglomerálódó térségben, a Cegléd-Nagykôrös-Kecskemét, ,„Három város" régiójában).

b) A falusi települések infrastruktúrájának területi különbségei

Az Alföld falvainak infrastrukturális ellátottsága a nagyobb települések miatt átlagosan jóval felülmúlja a tagoltabb felszínũ többi országrész apróbb falvainak ellátottságát. Az Alföldön belül is szoros a kapcsolat a települések lélekszáma és az alapellátás szintje, az intézményhálózat kiépültsége között.

A kéttucatnyi részmutatóból számított komplex mutató pontértékei alapján szerkesztett kategóriatérkép azt mutatja, hogy a viszonylag kedvezôbb infrastrukturális ellátottság a Közép-Tiszántúl, a Közép-Tisza-vidék, a Tisza mente, Dél-Békés, Észak-Bácska és Kalocsa térsége falusi térségeire jellemzõ. Leggyengébb az általános ellátottság Szatmárban, Beregben, Kelet-Szabolcsban, Békés és Hajdú-Bihar megye határmenti sávjában - hogy csak a nagyobb, összefüggõ homogén értékcsoportokkal jellemzett területeket említsük.

A falusi infrastrukturális intézmények körzetesitése a kisfalvas térségekben (fổként Szatmár-Beregben) a jobb közlekedési lehetôségekre is hivatkozással, kizárólag fiskális szemlélet alapján történt. A közösségi intézmények területi koncentrációjából nyert közvetlen megtakarítás, a csupán ökonomiai szempontú ,,racionalizálás” haszna a falusi társadalom szerves fejlôdése, fennmaradása szempontjából több mint vitatható.

A középfalvak infrastrukturális helyzetét tájegységenként eltérô sajátosságok jellemzik. A kertgazdálkodási-szôloôtermelố kultúrák térségeire átlag feletti színvonal jellemzố (a Duna-Tisza közi homokhát egyes részein, a Duna menti lapályon, Szeged környékén).

$\mathrm{Az}$ erôsen megcsappant tanyaállomány infrastrukturális szempontból is differenciálódott: a városközeli övezetekben (különösen az intenzív kultúrákban elért magasabb jövedelemmel összefüggésben, és a liberálisabb településpolitikai magatartás eredményeként) fejlődött az alapinfrastruktúra.

\section{A hálózati infrastruktúra jellemzôi}

A hálózati infrastruktúra tekintetében az Alföld igazából csak egy-két elemében van elmaradva a többi országrésztôl, mivel a közlekedési és energiaszállító hálózatok fó alkotói nem csupán regionális, hanem országos rendeltetésúek és nemzetközi kapcsolatokat is hordoznak. (Finanszírozásuk központi, sổt külföldi forrásokból történt.)

a) A közlekedési infrastruktúra

Az Alföld vasúti fôvonalai teljesítményben, technikai felszereltség terén nem maradnak el a többi országrésztôl, sổt felül is múlják azokat, és mindmáig jelentôs településfejlesztô, -éltetô, -fenntartó tényezô. Annál kedvezôtlenebbnek bizonyult - az amúgy is hátrányos helyzetû, periférikus agrártérségek léte szempontjából - számos kisforgalmú mellékvonal és gazdasági vasút megszüntetése. A forgalom közútra terelése ellehetetlenítette a közhasználatú közlekedést, fốként a teherszállitást, elősegítette a demográfiai 
eróziót is magába foglaló gazdasági kiüresedési folyamatok felgyorsulását, az érintett térségek , lecsúszását".

Az alföldi közúthálózat jóval ritkább az országos átlagnál, ami önmagában nem igazán hátrány, hiszen itt a sajátos, ritkább településhálózat miatt nincs is szükség olyan sürü hálózatra, mint a többségében apró- és kisfalvas Dunántúlon vagy Észak-Magyarországon. (A tanyáktól eltekintünk, mert egyelôre anakronisztikus követelmény a tanyák közúti kapcsolatának megteremtése.) A hiányosság a legegyértelmúbben az utak (különösen az alsóbbrendũek) gyenge minôségében mutatkozik meg. Az Alföldön az útminőség még csak lazán sem korrelál a különbözố területek gazdasági potenciáljával, jövedelmi viszonyaival.

Az Alföld lakosságszámhoz mért fajlagos gépjármüállománya a közeledés ellenére még jóval elmarad a többi országrészétól..$^{5}$

A kisebb gépkocsiállományhoz igazodóan, két megye kivételével, az Alföldön jóval ritkább az üzemanyagtöltõ állomások hálózata is.

A közúti közlekedési infrastruktúra fontosabb elemeinek együttes számbavételével elôállított komplex mutató alapján az Alföld megyéi - a legjobb értékü Csongrád megye kivételével - a gyengén közepes és fóként a gyengén ellátott kategóriába tartoznak. (Az ország 19 megyéje közül Csongrád a 7., Bács-Kiskun a 10., Jász-Nagykun-Szolnok a 11., Pest a 16., Hajdú-Bihar a 17., Békés a 18., Szabolcs-Szatmár-Bereg a 19. helyen áll.)

A közhasználatú szárazföldi közlekedési eszközök részben távolsági (nagyobb, központi települések közötti), részben vonzáskörzeti jellegư (centrumtelepülés és vonzott települések közötti) forgalom közvetítôi. E funkciók betöltése regionálisan eltérổ mértékben valósul meg.

A nemzetközi (vasút- és autóbusz-) vonalakkal való feltártság tekintetében az Alföld kedvezốtlenebb helyzetben van a Dunántúlnál. A belföldi fốvároscentrikus (sugaras) és transzverzális irányú, a távolsági közlekedést hordozó vasúti fôvonalak által nem érintett összefüggô terület a Budapest-Hatvan-Miskolc és a Budapest-Szolnok-DebrecenNyíregyháza-Miskolc fốvonaltól közrefogottan is, Nyugaton a Szolnok-Hatvan pályától határolva az Észak-Alföldön található. A második legnagyobb kimaradt területet a szolnok-debreceni és szolnok-békéscsaba-gyulai vasútvonalak, valamint a magyarromán határszakasz által közrezárt háromszög alkotja a Dél-Tiszántúlon (1. ábra). A távolsági transzverzális és centrális buszvonalak által egyáltalán nem érintett terület az ország északkeleti részén (a Jósvafô-Miskolc-Polgár-Nyíregyháza-Debrecen-Gyula vonaltól keletre) alkot kiterjedt, összefüggố fehér foltot. Ez gyakorlatilag azt jelenti, hogy az itteni lakosságnak elôször valamilyen eszközzel el kell jutnia azokba a városokba, ahonnét távoli helyekre el tud utazni.

Az egyes nagytájak, régiók, megyék közötti keresztirányú (az ország központját, a fốvárost elkerülö) forgalom fổ eszközei formálisan a csak egyes szakaszokon létezó, a transzverzális vonatokat helyettesiteni hivatott autóbuszjáratok. Lassúságuk miatt azon- 
ban az utasok helyettük általában inkább vállalják vasúton a kényelmesebb kerülôutat. Ezért a létrehozó szándékkal szemben csak kis mértékben váltak a nagy távolságra utazás eszközeivé, inkább - erốs utascserével - a rövidebb távú , láncközlekedést'" segítik.

Az Alföldön a legtöbb várossal - periférikus fekvése ellenére - Szegednek van közvetlen (vasúti + busz) összeköttetése fốként buszvonalai révén (2. ábra). Az utána következô Kecskemét elsôsorban az érintổ tranzitvonalaknak köszönheti magas közlekedési kapcsolati értékét.

A vonzáskörzeti közlekedés túlnyomó része a városok felé irányul. A megyeszékhelyek ugyan nagyban veszítettek adminisztratív-irányítási funkciójukból, az Alföldön azonban szinte kivétel nélkül ezek a legjelentôsebb gazdasági-foglalkoztatási-szolgáltató központok. Ennek ellenére a megyék kisebb-nagyobb térségeibôl (területük 9,2-41,3\%-ából) nem lehet közvetlen járatokkal elérni a megyeszékhely várost. A nem megyeszékhely városoknak, mint legközelebb fekvố szolgáltató központoknak, vonzáskörzetükbơl való rossz elérhetôsége is nehezíti a vidékiek életét.

Valamennyi, általunk vizsgált szárazföldi közlekedési (részben a pályákra, közlekedési eszközállományra, részben a közlekedés területi járatrendszerére vonatkozó) részmutatóból képzett komplex mutató alapján egyértelmüen megállapitható az Alföld elmaradottsága. Az alföldi megyék közül a legkedvezőbb helyzetben lévó Pest megye például országosan csupán az ötödik, az utána következô Csongrád megye a hatodik, JászNagykun-Szolnok megye a 11., míg Hajdú-Bihar és Bács-Kiskun megye a 13-14., Békés a 17., Szabolcs-Szatmár-Bereg pedig az utolsó, 19. helyet foglalja el.

Érdekes, hogy a térségek közlekedése és általános gazdasági-infrastrukturális szintje között inkább csak a szélsốséges kategóriákban van összefüggés.

A belvizi közlekedéshez kétségtelenül nem kedveznek a természeti adottságok, azonban a hajózás hallatlan elhanyagoltsága fôként a kényelmesség, a szervezetlenség, és érzéketlenség következménye. Sajnos, ma bármilyen konkrét javaslat a helyzet alapvetô megváltoztatására csupán megmosolyogni való illúziónak tũnhet. Kérdés, hogy a Rajna-Majna-Duna-csatorna megnyitása milyen mértékben növeli a Duna forgalmát, képes lesz-e fejlesztôerõként hatni a parti kikötõvárosokra?

A légi közlekedés mai formájában (a viszonylatokat, az utasok számát, a felszereltséget, a kapacitást tekintve) messze elmarad az 50-es évekbeli állapottól. Bizonyos potenciált jelenthet az egykori szovjet katonai repülôterek ,,polgárosítása' (például a debreceni berendezése Ferihegyet tehermentesítố nemzetközi légikikötôvé). 


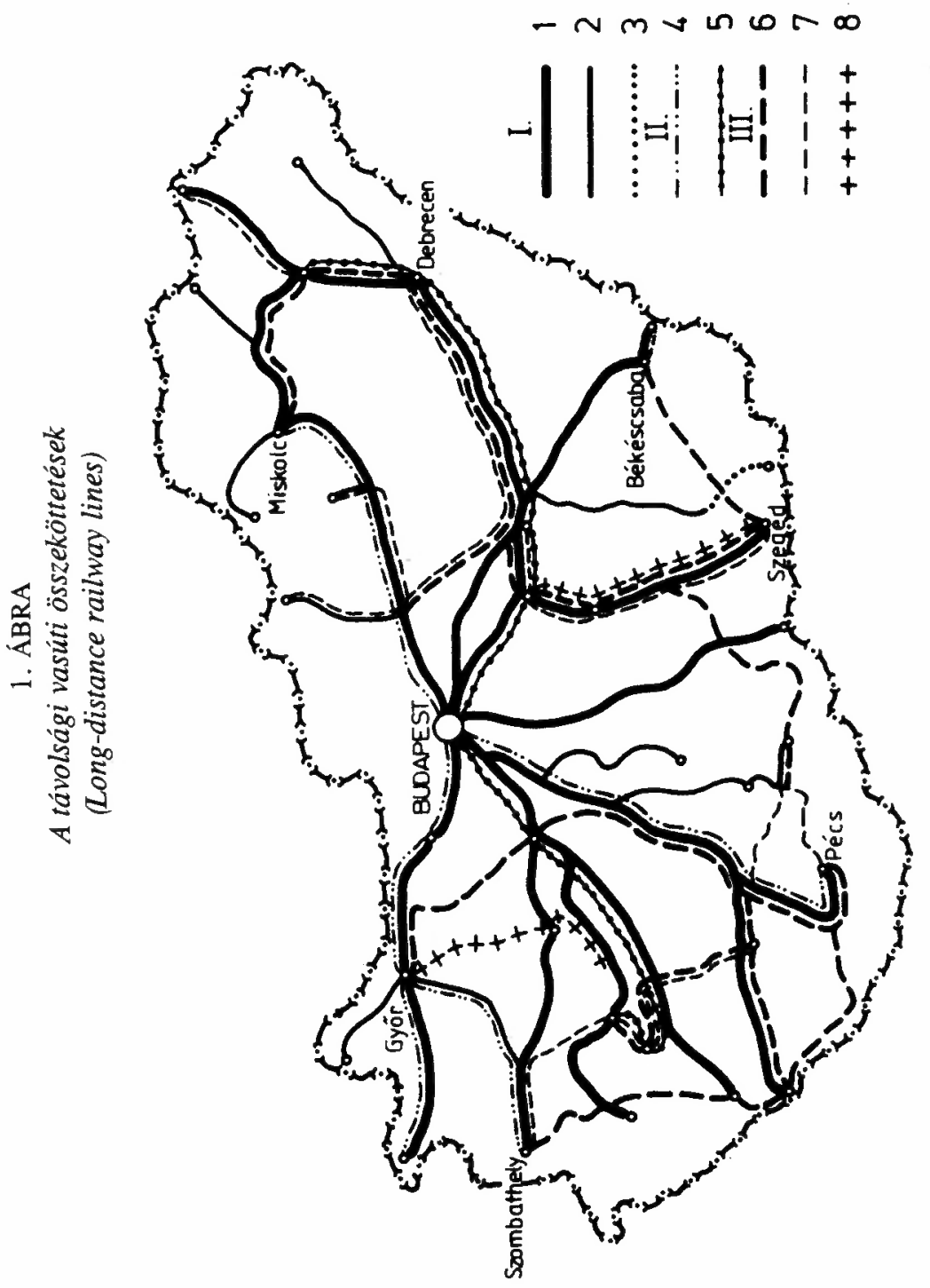



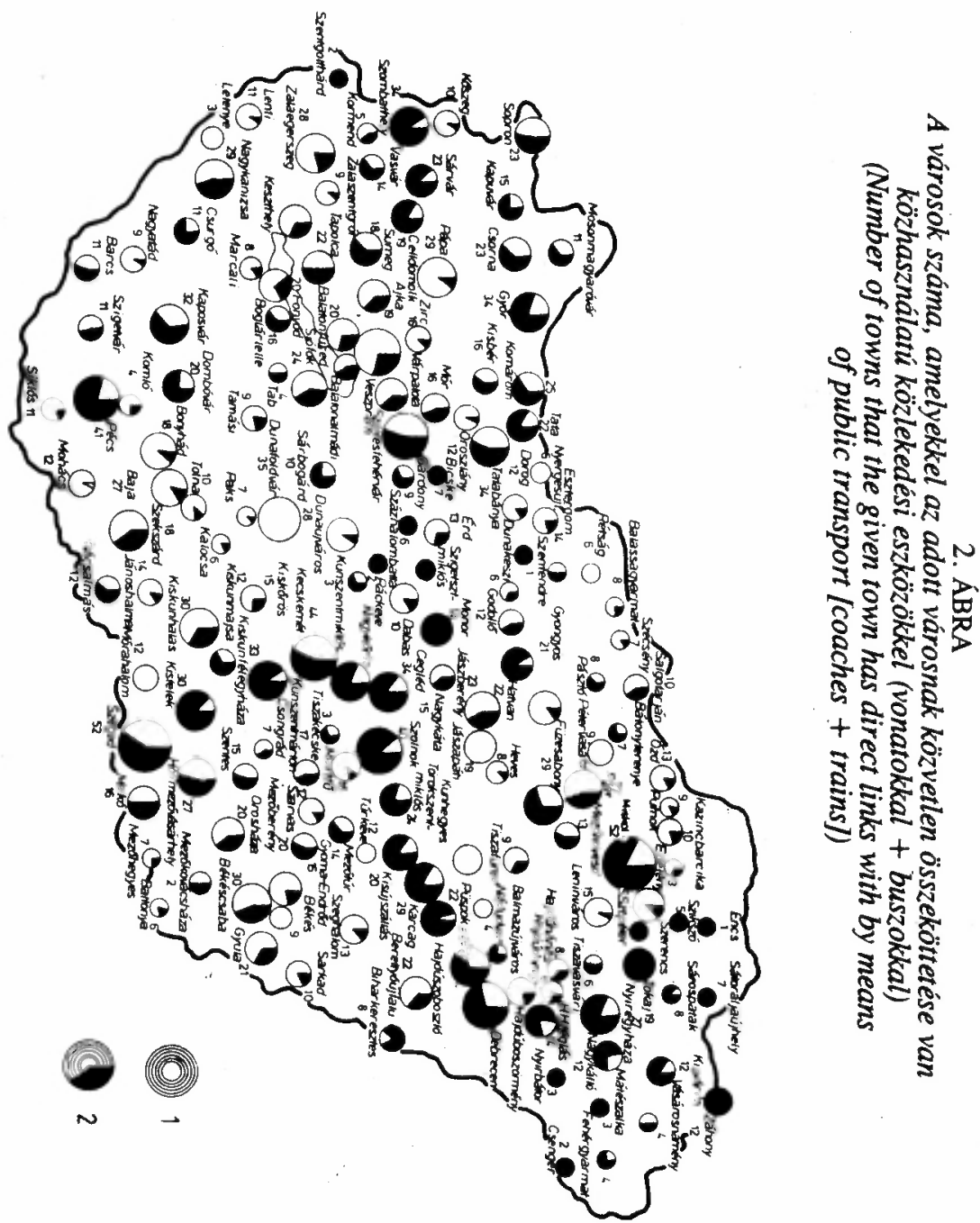
b) A hírközlési infrastruktúra

A hírközlésen belül meghatározó szerepe van a távbeszéló infrastruktúrának, mivel a fax- és adatátvitel-szolgáltatás is telefonvonalakon történik. A telefonellátottságban (a „telefon-fóállomások” fajlagos számában) az Alföld feltünōen leszakadt a többi országrésztổ. Csupán Csongrád megye tartozik az országosan is legjobban ellátott területek közé.

A települések közül a kisfalvak, valamint a tiszántúli kisebb agrárvárosok ellátottsága viszonylag a legrosszabb. A távbeszélổ használati értékét nagymértékben nờvelõ távhívásból ma még kimaradó legfontosabb területek közé tartozik a Duna-Tisza köze északi része, a kalocsai és kiskunhalasi vonzáskörzet, a Tiszazúg és attól északra a törökszentmiklósi, délre pedig a szentesin és orosházin át a mezôkovácsházi körzetig tartó rész, továbbá a Kelet-Tiszántúlnak a Körösök által közrefogott része, végül Szabolcs-SzatmárBereg megye fele (3. ábra).

A tömegkommunikációs eszközök közül a telex elterjedettségében az Alföld nagyjából az országos átlag körüli helyet foglalja el. A telexet lassan kiszorító telefax-készülékállomány tekintetében viszont jelentôs az Alföld elmaradottsága, mivel alig terjedt még el a Közép-Tisza-vidéken és Szabolcs-Szatmár-Beregben. A müholdas $t v$-szolgáltatásban közösségi hálózattal legjobban ellátott területsáv a Dunántúlról átnyúlóan a SzolnokTiszaújváros - Debrecen-Nyíregyháza városok által képzett vonal mente.

c) A távvezetékes energia- és vízszállító infrastruktúra

Az energiaszállító távvezeték-hálózatok tekintetében az Alföld kedvezõ helyzetben van, mert a ma még túlnyomóan keletrôl érkezố nemzetközi távvezetékek az Alföldön lépnek be az országba.

A nagynyomású földgáz-távvezetékek hálózatának textúrája egyértelmũen kelet-nyugati irányú, illetve a Budapest felé irányuló elemek uralkodnak, de vannak csatlakozási pontjai Észak-Magyarországgal és a Dunántúllal is. Ahogyan a kelet-európai szénhidrogénforrások súlya csökken energiagazdálkodásunkban és ugyanakkor a nyugati rendszerekhez való csatlakozásra egyre több intézkedés történik, úgy merevedik le az alföldi csôvezetékhálózat struktúrája. Az Alföld villamosenergia-ellátása ma túlnyomórészt dunántúli és észak-magyarországi erômüvekbôl $220 \mathrm{kV}$-os távvezetékeken és külföldi forrásokból történik (750 és $400 \mathrm{kV}$-os távvezetékeken), de az országos hálózat közvetítésével. A külföldi energia beszerzési forrásaiban bekövetkezó orientációváltás miatt az Alföldön a jövơben csak igen kevés távvezeték-építésre lehet számítani.

Az Alföld városainak (méginkább falusi településeinek) vízellátásában a regionális vízmüvek keretében, táv-vizvezetékekkel történô megoldások jóval kisebb szerepet játszanak, mint a dunántúli, sổt az észak-magyarországi térségekben. A legnagyobb területre kiterjedô fejlesztés Kelet-Békésben várható. 


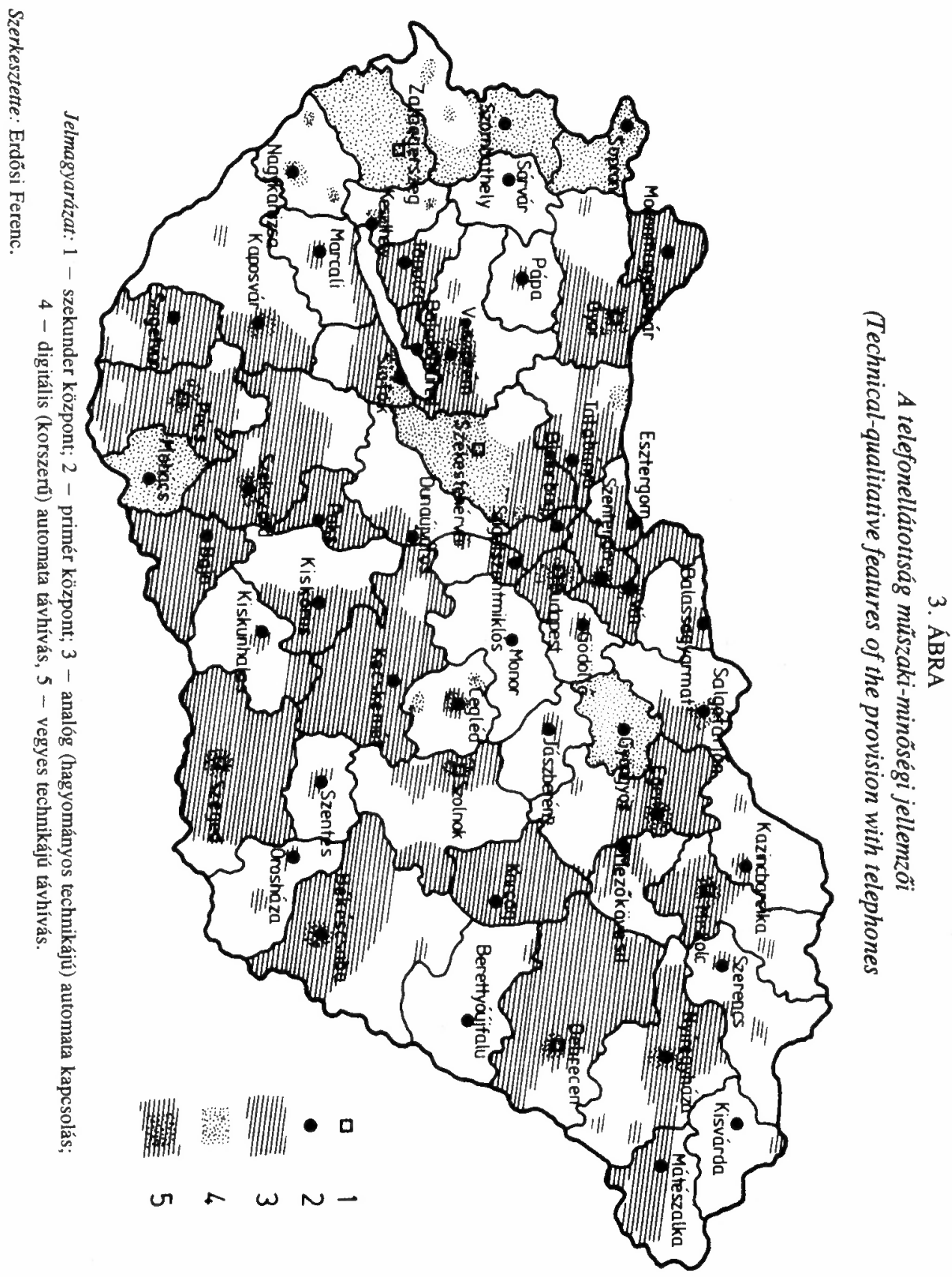


Tér és Társadalom 7. évf. 1993/3-4. 13-34. p.

\section{Az infrastruktúra-fejlesztés stratégiája és föbb feladatai az Alföldön}

\section{Az infrastruktúrának mint területfejlesztési eszköznek vállalatnagyságtól is függó reális lehetóségei}

A tổke területi mobilitását befolyásoló makrogazdasági helyzetet is figyelembe véve, a telephely-választásnak - az infrastruktúrán kívül - még jó néhány területgazđasági, mikroökonómiai, jogi feltétele, tényezôje van, és csak ezek többségének kedvezổ együttállása eredményez pozitív döntést. Tisztában kell lenni tehát azzal, hogy a szinte kizárólag infrastruktúrára (mintegy a termelési feltételek megelôlegezésére) alapozott fejlesztési program korántsem biztos, hogy eredményt hoz, amint azt a Szabolcs-Szatmár-Bereg és Békés megyei, túlzott várakozásokkal szembeni, igencsak mérsékelt iparosodás is igazolja. Külföldi példákat is emlithetnénk azzal a tanulsággal, hogy egyedül az infrastruktúra-fejlesztéstôl (pl. elôközmưvesített ipari park területtôl) nem várható automatikusan termelố tevékenység letelepedése, az elmaradott vagy depressziós térségek fellendülése.

Ha viszont adott a telephely-létesítés többi feltétele, csak éppen a megfelelô infrastruktúra hiányzik, a telephely melletti döntés aligha lesz pozitiv, mert bizonyos fajta infrastruktúrák bizonyos szinten való megléte a termelés ,,sine qua non"-ja, s a termelési technológiák infrastruktúra-érzékenységének növekedésével az ipari tôke egyre igényesebb az infrastrukturális ellátottsággal szemben (pl. elổérbe kerülnek a , puha” infrastrukturális tényezôk, a szellemi szféra minôségi jegyei). Az infrastruktúrának a telephelyi döntéseknél elsôsorban a közepes vállalatok számára van jelentôsége, a transznacionális nagyvállalatoknál kisebb költségtényezóként kevésbé, a többnyire lakóhelyen létesülố kisvállalatok számára pedig e tényezố irreleváns. Végsố soron tehát az infrastruktúra nélkülözhetetlen, de nem elégséges elófeltétele a regionális fejlesztésnek.

Az infrastruktúra Alföld-fejlesztésben való helyének meghatározásakor figyelembe veendố, hogy a makrogazdasági szinttel és a termelés szférájával ellentétben az infrastruktúra szférájában az intenzív extern hatások miatt, nem számolhatunk a piaci folyamatok egyensúlyteremtó, a kereslet-kínálat viszonyának megfelelóen alakuló reguláló hatásával. Ezért szükségesek a jogi-politikai, illetve mûszaki (terület-illetve városrendezési) beavatkozások, korrekciók. Éppen a tovagyũrũzô, átháritható, externalizálható hatások miatt a makro- és mikroszintû optimum nem esik egybe. Számolni kell azzal, hogy oszthatatlansága, a használatából nem kizárhatóság, és hosszú élettartama miatt, az infrastruktüra nagymértékben képes az adott térbeli struktúrát konzerválni.

Az infrastruktúra hiánya a hatékony térbeli struktúra kialakulását akadályozza azzal, hogy nehezíti a termelési tényezók hatékony térbeli mobilitását (pl. a lakáshiány miatt a munkaerố nehezen tud a megfeleló helyre áttelepülni), kemény akadálya lehet a piaci alkalmazkodásnak és integrációnak (pl. a telefon hiánya, a szũk raktárkapacitás, a határállomások szủk keresztmetszete, a pénzügyi infrastruktúra fejletlensége). 


\section{Az Alföld speciális jellemzôinek figyelembevétele a fejlesztésnél}

Egyelôre a régiók sajátos vonásaitól független, általános (nemzetkôzi, nemzeti szintứ) gazdasági-társadalmi tényezốk (meglehetôsen alacsony színvonalú területi differenciáltság mellett) hatnak igazán az infrastruktúra fejlôdésére, azaz túlsúlyosak a helyi-térségi karakterbôl adódó megoldási módokkal szemben. Ezt még erôsíti az a körülmény, hogy az Alföld az ország területének mintegy felét teszi ki, tehát túl nagy ahhoz, hogy az infrastruktúra-fejlesztés politikában markánsan megmutatkozzanak valamilyen sajátos vonások. A hagyományos termelési és településszerkezet alapján mindenesetre „,mezôgazdaságbarát”, ,tanyabarát”, ezenfelül ,,környezetbarát” megoldásváltozatokra van szükség az infrastruktúra fejlesztésében.

\section{Fôbb célok és feladatok}

\section{a) Rövid távú taktikai lépések}

A helyi szintũ alapellátás a legsürgốsebben megoldandó feladat, fôként az elmaradott térségek falvaiban, kisvárosaiban. A tanyavilágban látványos fejlôdésre néhåny éven belül nemigen lehet számítani (a módos emberek által üdülổnek, szellemi alkotó környezetnek, mũhelynek használt, valamint az agglomerációs övezetekben jövedelmezố, intenzív mezôgazdasági termelés, esetleg terményfeldolgozás telephelyéül szolgáló tanyafarmok kivételével), mint ahogyan a nagyobb városok súlyos problémái közül is csak néhánynak a mérséklésére, esetenként megoldására látunk lehetôséget. Számolni kell azzal, hogy mind az ipari nagyvállalatok, mind a mezógazdasági üzemek közvetlen szerepe nagymértékben csökken a települések infrastruktúra-fejlesztésében; áttételesen (adókon keresztül) természetesen továbbra is fejlesztơ tényezôk maradnak, de beleszólásuk a fejlesztés mikéntjébe alig lesz. A nagyvállalatok mecenatúrájának megszünése különösen olyan iparvárosokban okoz nehézséget, mint Martfũ, Tiszavasvári, Tiszaújváros, de bizonyos mértékig a nem kifejezetten ipar-, de erôsen iparosodott vărosokban is.

$\mathrm{Az}$ alapellátásban a legsürgôsebb teendố az egészséges ivóvizzel való ellátás megteremtése, és a csatornázottság felzárkóztatása a túlzottan nyitott közmũolló katasztrofális környezeti hatásainak felszámolása érdekében (különösen az e téren nagyon lemaradt Szabolcs-Szatmár-Bereg, Jász-Nagykun-Szolnok és Békés megyékben, illetve Jászapáti, Kiskunmajsa, Tiszakécske, Nádudvar, Hajdúdorog, Bácsalmás, Biharkeresztes, Hajdúhadháztéglás városokban.) Bôvíteni kell a szennyviztisztító-kapacitást, javítani a tisztitás hatåsfokát.

Egészséges ivóvíz viszonylag kevés helyen áll megfelelố (,,közmûvesíthetô") mennyiségben rendelkezésre, ezért a települések ellátásában különösen nagy szerepet kell játszaniuk a regionális vezetékrendszereknek. 
A bölcsõdék, óvodák, napközi otthonok iránti igények feltehetõen nem növekednek; annál nagyobb figyelmet kell fordítani az általános iskolai infrastruktúra minöségi fejlesztésére.

Meg kell erôsiteni az egészségügyi alapellátást, törekedni kell a háziorvosi rendelôk zsúfoltságának megszüntetésére.

Ahol még nincs helyi tömegközlekedés, de van arra igény, meg kell teremteni; a hírközlést - szükségmegoldásként - nyilvános telefonállomások létesítésével kell közhasznúvá tenni a faluprogram keretében kiépítendổ társasági hálózatokon belül.

A városok központi negyedeit részben városperemi elkerülö, részben településen belüli tehermentesitô utakkal, felüljárókkal kell óvni a túlzott forgalomtól.

Aligha sorolható sorrendiségben az elổbbi feladat mögé a középfokú intézményhálózat kiteljesitése az utóbbi időben nem éppen megalapozottan várossá elöléptetett településeken. Kórházakra van szüksége csaknem minden második alföldi városnak, középiskolákat kell létesíteni Hajdúdorogon, Hajdúhadháztégláson, Mórahalmon, Nádudvaron; növelni kell mintegy 15 városban a középiskolák kapacitását, 8 városban pedig a tantestületek összetételét kell javítani.

Az új igazgatási viszonyok ugyan nem kedveznek a városok és vonzáskörzetük egységes, koordinált tevékenységmegosztáson alapuló fejlesztésének, a középfokú ellátásban mégis feltétlenül szükség van a városok és vonzáskörzeteik ,,egészséges”, összehangolt funkcionálására. Törekedni kell a városi nagy lakótelepek középfokú intézményekkel való jobb ellátására, hogy a középfokú szolgáltatások igénybevételéhez ne kelljen az itt lakóknak a hagyományos városközpontba utazni.

A kisebb és közepes régiók vízellátását regionális vízvezetékrendszerrel kell megoldani, közlekedési kapcsolataikat pedig az utazási távolságokat csökkentổ összekötôutakkal, többirányú autóbuszvonalak létrehozásával ajánlatos javítani.

b) Hosszú távú fejlesztési stratégia

Prioritás illeti a távolsági (interregionális és nemzetközi) közlekedési infrastruktúra fejlesztését. A vasúti és közúti magisztrálék versenyében az Alföld és egyben az ország nagy távlatú érdekeinek megfelelõen $a$ vasútnak kell elsôbbséget adni. Nagyteljesítményũ vasutakkal tudunk eleget tenni - a környezet óvása mellett - tranzitszállitási kötelezettségeinknek. A fôvároscentrikusság oldása érdekében meg kell teremteni a többi országrésszel való közvetlen, hatékony kapcsolatot, beleértve a szükséges folyami hídépítéseket, fôutkorrekciókat, vasúti rekonstrukciókat, helyenként új nyomvonalon kiegészító pálya építéseket.

A hiányosságok megszüntetésére mutatós eszköz kínálkozik. A Déli Autópálya, azonban elsõsorban a nemzetközi tranzit eszköze lenne, vele idegen érdekek kiszolgálása közben ,,kapcsolt áruként importálnánk" egy olyan méretũ környezetszennyezôdést, devianciát, hogy ésszerübbnek látszik a transzverzális forgalom kielégítésére nagyteljesítményủ villamosított vasutat létesíteni, amely alkalmas lehet a kamionok jó részének távolsági 
szállítására is (,,gördülô országút”)). Meg kellene építeni a Szeged - Bácsalmás pályát, a folytatását képezõ Bácsalmás -Baja-Dombóvár szakaszt pedig elsốrangú pályává kellene átépíteni. A Kecskemét-Dunaföldvár-Mezõfalva pályalánc elsõrangúsításával, a földvári híd teljes rekonstrukciójával egy további nagyteljesítményũ összeköttetés jöhetne létre a Közép-Dunántúllal, a fôváros teljes elkerülésével.

A Füzesabony-Tiszafüred-Karcag mellékvonal ,,fổvonalasítása" Észak-Erdélyt hozná közelebb Észak-Magyarországhoz és Közép-Szlovákiához; folytatásában a KálKápolna-Kisterenye pálya korszerũsítése is feltétel. Ugyancsak régi hiányt pótolna a Tiszafüred-Debrecen mellékvonal építése, amely az Eger és Debrecen térsége közötti közvetlen összeköttetést szolgálná. Nagyon hiányzik az Észak- és Dél-Tiszántúl két nagyvárosa, Debrecen és Békéscsaba közötti direkt vasúti összeköttetés is, amit a 43. számú másodrendũ fốközlekedési út nem képes helyettesíteni.

A közúthálózat fejlesztését a jövôben $a$ valós követelményekhez való jobb igazodással kell megtenni. Sajnos, a tárca „,Országos közúthálózat 1991-2000. évekre szóló fejlesztési program"-ja irreálisan nagyszabású, a lehetốségeinktôl teljesen elrugaszkodott útépítésekkel számol, amelyeknek becslésünk szerint jó, ha az egynegyede elkészül az ezredfordulóig.

Az Alföld vízi útjait jobban ki kell használni, megfelelố kiegészítố infrastruktúrákkal és reális tarifa alkalmazásával életképessé tenni. Bôviteni kell a légiközlekedés lehetôségeit.

A hírközlésben - a mennyiségi fejlesztés mellett - a szolgáltatás minõségét alapvetôen javító távhivásos rendszert kell mindenütt megvalósítani, és lényegesen elôre kell lépni a digitális elvũ hálózat, illetve központok kiépítésében.

A nagynyomású távolsági földgázvezeték-hálózat kiegészítésén, egyes szakaszok tehermentesítésén túlmenõen (a további súlyos környezetkárosítást elkerülendô) fokozatosan $k i$ kell cserélni a régebbi, sok helyen anyaghibás, könnyen törố csôvezetékeket.

A villamosenergia-távvezetékhálózat, transzformátorok rekonstrukciójával biztosítani kell a biztonságos és többirányú energiaellátást.

Az Alföld, különösen városainak fejlổése nem kis mértékben attól függ, hogy milyen lesz szellemi arculatuk, szellemi infrastrukturális potenciáljuk. Konkrétan: a felsôfokú képzésnek és a kutatásnak a mennyiségi fejlõdésen túlmenõen minổségi-strukturális megújulással, a szakmai-tudományági szerkezet kedvezõ irányba való átalakulásával kell együttjárnia. Különös szerepük lehet az Alföld szellemi infrastruktúrájában a hagyományos kis és közepes kultúr- és iskolavárosoknak, illetve a mezôgazdasági innovációban kitûnổ kutató-adaptáló központoknak, ami mellett szükség van súlypontképzésre is.

A fejlesztési feladatok nemcsak a vonatkozó térségek nagysága és a megvalósítás idốtartama, hanem településkategóriák szerint, sốt környezetvédelmi szempontok szerint is csoportosíthatók, de az utóbbiak részletezésétôl terjedelmi okok miatt eltekintünk. 


\section{Az infrastrukturális fejlesztési feladatok megvalósitásához szükséges eszközrendszer}

Az infrastruktúra-fejlesztés a tulajdonviszonyok átalakulásával mindinkább sokszereplôssé válik. A helyi infrastruktúra gazdáivá, üzemeltetổivé mind nagyobb mértékben a helyi önkormányzatok válnak, melyeknek különösen két szempont érvényesítésére kell törekedniük: nevezetesen, az érdekek védelmére, egyeztetésére, valamint együttmüködésük megszervezésére.

Az alapellátás, az ahhoz szükséges létesítmények üzemeltetése általában minden életképes településen ,,belügy". Ez a legegyértelmübben a nagy- és óriásfalvakra igaz, nem szólva a városokról. Viszont a szatmár-beregi és más térségek kisfalvai önmagukban nem igazán képesek gazdaságos infrastruktúra-fejlesztésre, ezért együttmúködésük nélkülözhetetlen, mint ahogyan a többközpontú városi agglomerációk, városegyüttesek önkormányzatai számára is komoly gazdasági és egyéb elổny származhat a koordinált együttmúködésböl.

Az önkormányzati törvény az integrációnak többféle szervezeti formáját ismeri el. A gyakorlatban ehhez a kistérségi-tájegységi szövetségek országos településszövetségeknél (pl. a már megalakult tiszazúgi, jászsági, szolnoki agglomerációs, Nagykun városi stb. és az alakulóban lévő̉k) reálisabb keretet nyújtanak. A leghatékonyabb szervezésre az önkormányzati társulások (pl. a megyei közgyũlés által szervezett megyei szintứ társulások), a vállalkozási irodák, újabban pedig az alapítványok képesek.

Az infrastruktúra finanszírozása az idôközben végbemenô privatizációs folyamat által is modifikáltan meglehetôsen változatos formában történik a jövốben:

- A nagyregionális, országos léptékú vonalas infrastruktúra-rendszerek (vasút, közút, hírközlés, távvezetékek) kiépítése, fenntartása ma még állami költségvetésbôl történik állami szakvállalatok keretében. Helyzetük ellentmondásos: egyfelôl nemzetgazdaságistratégiai szintũ érdek fũzôdik ahhoz, hogy az állam akarata érvényesüljön a kizárólag profitorientált tốkebefektetổkkel szemben, másfelôl hatékonyság-javítási, korszerũsítési célból részleges vagy éppen teljes privatizációjukra törekednek - koncessziók formájában a külföldi tôkét is bevonva. Nem világos, hogy milyen tulajdonban, valamint kinek a kezelésében üzemelnek majd az autópályák és hogy a fôvárosi EXPO-val kapcsolatos vidéki infrastrukturális beruházások kiterjednek-e az országos-regionális infrastruktúrára is, vagy csak a települési infrastruktúrát érintik.

- A kommunális (települési) infrastruktúra fejlesztése, fenntartása, müködtetése alapvetổen az önkormányzatok feladata. Anyagi eszközeik azonban még sokáig aligha lesznek elegendôek a hiányok pótlására. Szükség van ezért a központi költségvetés támogatásá$r a$, a lakossági, vállalati, alapítványi hozzájárulásokra, az önkormányzati vállalkozásokból származó jövedelmekre. 


\section{Jegyzetek}

1 A legsürgõsebb csatornafejlesztésre azokban a városokban van szükség, amelyekben a közcsatornával való ellátottság a legnagyobb mértékben maradt le a vezetékes vízellátottságtól: Jászapáti (több mint 18-szor több lakásban van vízvezeték, mint csatorna), Kiskunmajsa (csaknem 15-ször), Tiszakécske (csaknem 13-szor), Nádudvar és Hajdúdorog (majdnem 9-szer), Bácsalmás (majdnem 8-szor), Biharkeresztes és Hajdúhadháztéglás (több mint 7-szer).

2 Az óvodák átlagos kapacitása a megyeszékhelyeken 1990-ben - Debrecen kivételével - lényegében megfelel a helyi igényeknek, viszont a többi város közül tucatnyira a zsúfoltság jellemzõ. (Kisteleken, Dabason kb. 30\%-kal több volt az óvodás a hivatalos kapacitásnál!) Az általános iskolai infrastrukturális ellátottság terén a megyeszékhelyek kategóriájára a viszonylagos kiegyenlítettség a jellemzó. (A legrosszabb helyzetben levỗ Debrecen és a legjobb helyzetú Békéscsaba között csupán mintegy 10\%-os a különbség.) Ezzel ellentétben a többi város szélsõ esetei (Hajdúnánás, illetve Battonya) között már nagy, mintegy $35 \%$-os a különbség. Feltũnõen nagy az egy tanteremre jutó tanulólétszám az Alföld két északkeleti megyéjének városaiban. Ez azonban feltehetõen csak virtuális zsúfoltság, mivel inkább az országos, illetve az alföldi átlagnál hagyományosan több gyerek szükségletéhez igazodás, mint a tényleges túlzsúfoltság tényével állunk szemben. Mũszaki megoldást itt a nagyobb befogadóképességũ tantermek építése jelenthet. A megyeszékhelyek középiskolai infrastrukturális ellátottságának jellemzôi az általános iskolaihoz nagyban hasonlítanak. A középiskolák jó részét az utóbbi évtizedekben hozták létre, különösen a kisvárosokban, de négy város még ma is kénytelen nélkülözni ốket.

A megyék sorrendje a bolti alapterület és a forgalom együttes figyelembevétele alapján: összességében az elsô két helyet (holtversenyben) Csongrád és Bács-Kiskun megye foglajja el, Békés a harmadik, HajdúBihar a negyedik, Jász-Nagykun-Szolnok megye az ötödik helyen áll, az utolsó kettó pedig SzabolcsSzatmár-Bereg és Pest megye. Pest megye, de bizonyos mértékig Jász-Nagykun-Szolnok megye forgalmát is negativan befolyásolja a közeli fôváros óriási kereskedelmi potenciálja, különösen az iparcikkforgalom terén. A határmenti megyékben tömegesen jelentkezô bevásárló turizmus viszont alig érhetổ tetten az ottani kiskereskedelmi infrastruktúra állapotában, mert az üzletelés túlnyomó része piacokon, utcán, lakásokban történik.

4 Egyedenként is világosan megmutatkoztak (-nak) a fổ hiányosságok (általában a városi funkciók gyakorlásához szükséges intézmények terén, némelykor vízellátásban, energiaellátásban), és ennek megfelelő̃en a fejlesztésben különböztek a fỗ teendốk (pl. Debrecenben a vízellátás, Békéscsabán az egészségügyi ellátás kórházépítéssel, az új megyeszékhelyeken - Szegeden, Békéscsabán, Kecskeméten - az igazgatási intézmények székházainak építése stb.).

5 A személygépkocsi-ellátottság eléggé szorosan korrelál a lakossági jövedelmek mértékével. Ma már az autó a második (és a harmadik) gazdaságban elért jövedelmeket, illetve a kisvállalkozási tevékenységek (beleértve a kisfarmert) gyakoriságát is indikálja. (Erre is visszavezethetô Bács-Kiskun megye országos első helye és Szabolcs-Szatmár-Bereg utolsó helye.) Ezen kívül az autósunrũség lazán összefügg a településnagyságrenddel és némely esetben a rászorultság mértékével is. Furcsa módon, a tehergépjármü-állomány területi megoszlása alig hozható összefüggésbe a termelési szféra fejlettségével. 


\section{PECULIARITIES OF THE INFRASTRUCTURE IN THE GREAT UNGARIAN PLAIN}

\section{FERENC ERDÔSI}

1. In matters of communal infrastructure, the underdeveloped situation of the Great Hungarian Plain in comparison with the national average decreased during the last half century.

a) Especially in availability of flats for housing this region is significantly approaching to the more developed macroregions of Hungary. The number of flats, the rate of construction of new or quasi-new flats was independent of, or even opposite to the population's incomes. This was partly because of the self-exploiting way of life, and partly because of the considerable state support following natural disasters. In matters concerning public utilities however, the handicap is still very strong. Despite the spectacular development from the very low level, there is a great gap between the public utilities in the plain as compared with other regions. (Even among many towns the number of the flats with tap water is 18 times higher than those with sewerage.) In matters of the housing conditions in the broader sense (complex index consisting of size, equipment, public utilities), among the Great Plain counties the situation of Csongrád is the most favourable. Worst one is Jász-Nagykun-Szolnok; the first of the towns is Szeged and the worst is Kecskemét.

b) Within the communal institutional infrastructure the (quantitative indices, of the) availability of educational-cultural infrastructure shows quite an unfavourable picture of the Great Plain, and the professional structure of education is inadequate for the needs of the macroregion. Though there has been a considered improvement in the situation of health care, there are huge differences between certain areas and settlements, partly as a function of the distance from the medical universities.

c) In matters of retail trade infrastructure, the Great Plain is close to the national average, but the development took place with strong concentration. The rate of the number of public accommodation establishments in the Great Plain is unreasonably low.

In matters of the broader-sense communal infrastructure the most desperate situation can be observed in the small agrarian towns (the so-called Nagykunság and Hajdú towns). It is sad that the advantages of the clusters of settlements situated close to each other (offering the chances for cooperation) could not be exploited during the infrastructural developments. On the other hand, the infrastructural availability of the Great Plain villages is significantly better than that of the much smaller villages in the other parts of the country. 
Erdősi Ferenc : Az Alföld infrastruktúrájának jellemzői és föbb fejlesztési feladatai

(Peculiarities of the Infrastructure in the Great Hungarian Plain)

Tér és Társadalom 7. évf. 1993/3-4. 13-34. p.

TÉT $1993 \backsim 3-4$

\section{Within network infrastructure}

a) in matters of the complex index derived from all the land transport partial indices, the situation of the Great Plain is a bit less favourable. It is to be considered that between the level of transport and general economic activity and infrastructure of the regions, there is a relationship only in the extreme categories.

b) In matters of telecommunicative infrastructure the Great Plain is strikingly less developed than the other parts of the country.

c) If we look at the energy transmission lines, the Great Plain is in a favourable situation. Most of the international transmission lines enter the country here. In the future, with possibly strengthening western orientation the advantage deriving from this situation will lose importance.

3. In the strategy of infrastructural development the special (regional and local) features should be taken into consideration as much as possible, also ,,agriculturefriendly", ,tanya-friendly", and ,,environment-friendly" solutions are needed. The financial support of infrastructure can come from different sources and in different forms in the future, also modified by the unfolding privatisation process.

Translated by Zoltán Raffay

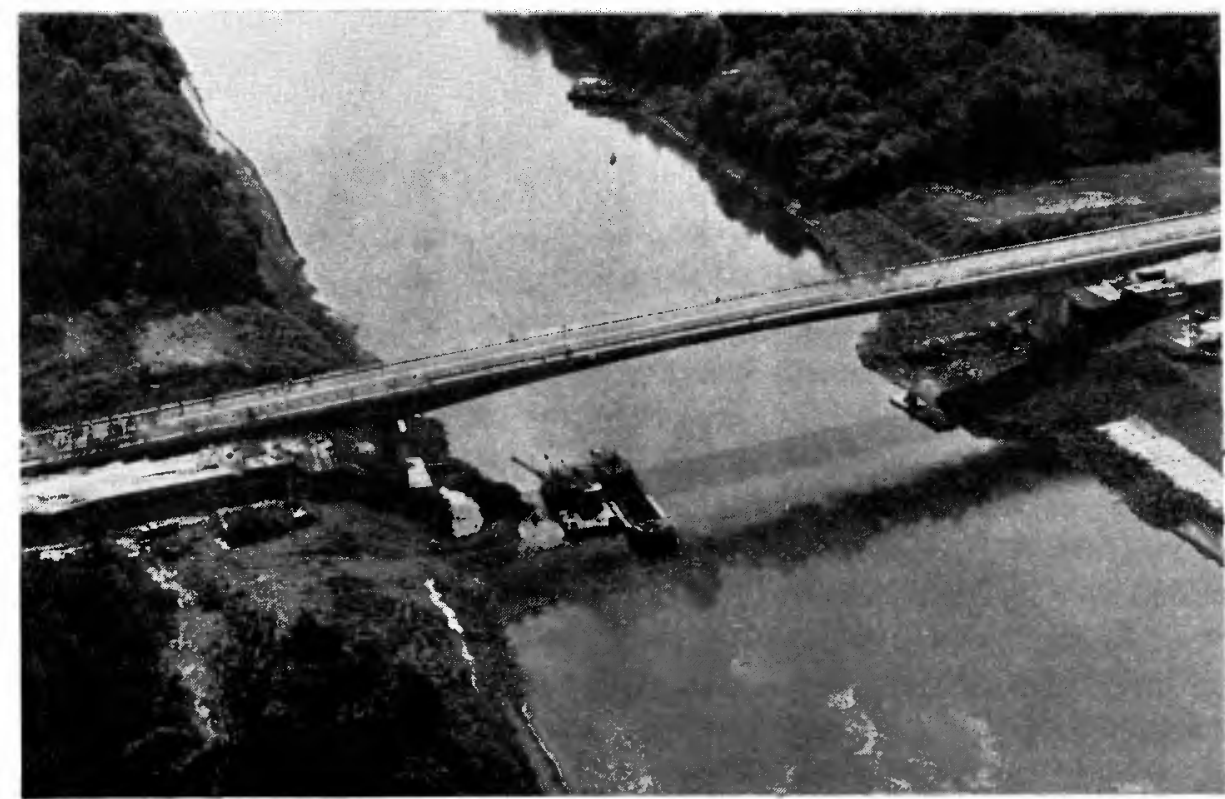

" „Tanya" is the Hungarian name for scattered farms. 